\title{
Effect of 1-Methylcyclopropene on Shelf-Life and Postharvest Qualities of Four Annona (Annona spp.) Species in Sri Lanka
}

\author{
G.P.M. Wijesinghe, G.D.K. Kumara and J.B.D.A.P. Kumara*
}

\begin{abstract}
Annona (Annona spp.) is a tropical underutilized fruit with growing demand in both local and export markets for their distinct tastes and promising health benefits. However, vulnerability to postharvest damages with the short postharvest life of this commodity has significantly affected their market potential. The present study attempts to extend postharvest life while maintaining postharvest qualities in Atemoya (Annona atemoya), Bullock's heart (Annona reticulata), Soursop (Annona muricata) and Sugar apple (Annona squamosa).
\end{abstract}

The experiment was conducted according to the Complete Randomized Design (CRD) using four treatments. Fruits were treated with $0,0.3,0.6$ and 0.9 $\mu \mathrm{L} \mathrm{L}^{-1} 1$-Methylcyclopropene (1-MCP) for 15 hours and stored under ambient temperature $\left(27 \pm 1^{\circ} \mathrm{C}\right)$. Fresh weight loss,

Department of Export Agriculture, Faculty of Agricultural Sciences, Sabaragamuwa University of Sri Lanka.

*arunajbd@gmail.com

https://orcid.org/0000-0003-1176-1246

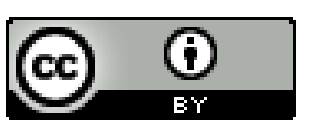

This article is published under the terms of the Creative Commons Attribution 4.0 International License which permits unrestricted use, distribution and reproduction in any medium provided the original author and source are credited. firmness, total soluble solids, titratable acidity and peel colour changes were evaluated in two-day intervals.

Fruit weight loss, firmness loss and concentration of titratable acidity showed strong positive correlation with time. Among the treatments, Annona fruits treated with $0.6 \mu \mathrm{L} \mathrm{L}^{-1} 1-\mathrm{MCP}$ reduced the chlorophyll degradation, fresh weight loss, total soluble solids and firmness loss. Peel colour indices $L^{*}$ and $b^{*}$ could be used to detect ripening of Annona. This study provides different 1-MCP concentrations that are effective to increase the postharvest life and postharvest qualities of four selected Annona species in Sri Lanka.

Keywords: Annona spp., 1-MCP, Postharvest management, Under-utilized fruit.

\section{INTRODUCTION}

Postharvest management is the main quality dependent factor of any horticultural commodity. It includes all kinds of postharvest treatments. Freshly harvested fruits and other horticultural commodities undergo different postharvest management practices to increase their postharvest life, minimize losses and add value to the product (Ramady et al., 2015). 
Worldwide fruit production is over about 850 million metric tons (FAO statistics, 2018) per year. But worldwide postharvest fruit losses are as high as 30 to $40 \%$ and even much higher in some developing countries due to inappropriate post-harvest management (Ekanayake and Bandara, 2002). Average postharvest losses of fruits in the South Asian region are in the range of 20-50\% (Khalid et al., 2011; Gautam and Bhattarai, 2012; Wasala et al., 2014).

Annona which is considered an underutilized crop in Sri Lanka, is a tropical fruit in the family Annonaceae (Ratnayake et al., 2020). Annona contains a remarkable amount of carbohydrates, proteins, fat, fibre, vitamins and minerals. Annona has a growing demand in the local and export market due to distinct taste and promising health benefits. Atemoya (Annona atemoya), Bullock's heart (Annona reticulata), Soursop (Annona muricata) and Sugar apple (Annona squamosa) are major Annona species grown in Sri Lanka (Heenkenda et al., 2009; Dilrukshi et al., 2020). All four species have huge market demand, for both processed and fresh fruits.
Family Annonaceae is classified as climacteric: with significant ethylene $\left(\mathrm{C}_{2} \mathrm{H}_{4}\right)$ production and high respiration rate during fruit ripening as well as with short postharvest life (Prasanna et al., 2000). Thus, Annona shows high postharvest losses resulting in short postharvest life and poor marketable quality.

Ethylene is well documented as being the ripening hormone of climacteric fruits (Burg and Burg, 1967; Bruinsma and Paull, 1984). At a certain maturation stage, ethylene links to its binding-site in the cell and promotes several alterations which culminate in the ripening and senescence of fruits (Lelievre et al., 1997). Such Ethylene actions can be blocked by some compounds such as 1Methylcyclopropene (1-MCP) which acts as an antagonist (Sisler and Serek, 1997). It is a beneficial nontoxic commercial product, recommended to use as post-harvest treatment for fresh horticultural products over 50 countries to improve the postharvest life and qualities (Mahajan et al., 2014; Tomala et al., 2020). The 1-MCP can reduce the effect of ethylene and delay fruit ripening and senescence. It can greatly reduce the respiration rate in the fruits and then reduce the fruit and flesh 
softening, chlorophyll degradation, physiological weight loss and the fruit decay (Tucker et al., 2017).

Therefore, this study was carried out to evaluate the postharvest life and postharvest qualities of four Annona species (Atemoya, Bullock's heart, Soursop and Sugar apple) treated with 1-MCP.

\section{MATERIALS AND METHODS}

\section{Experimental Site and Plant Materials}

The experiment was conducted in 2018 under laboratory conditions at Sabaragamuwa University of Sri Lanka.

Uniform Annona fruits (i.e. same size, shape) of Atemoya (Annona atemoya), Bullock's heart (Annona reticulata), Soursop (Annona muricata), Sugar apple (Annona squamosa) and freshly harvested at horticulture maturity were used as experimental material (Figure 1).

\section{Treatment Application}

The treatment solution was prepared by dissolving powder form 1-MCP (4\%) in $\mathrm{NaHCO}_{3}(10 \%)$ solvent. Then, it was diluted to the concentrations of $0.3,0.6$ and $0.9 \mu \mathrm{L} \mathrm{L}^{-1}$ to be used as treatments.

In each treatment, randomly selected fruits were exposed to the emitted gas of above solution in air tight chambers for 15-hours. Then, all treated Annona fruits were kept at room temperature $\left(27 \pm 1^{\circ} \mathrm{C}\right)$ for the observations. The experiment was replicated three times (four fruits per replicate), was arranged according to Completely Randomized Design (CRD). The observations were made in two days intervals.
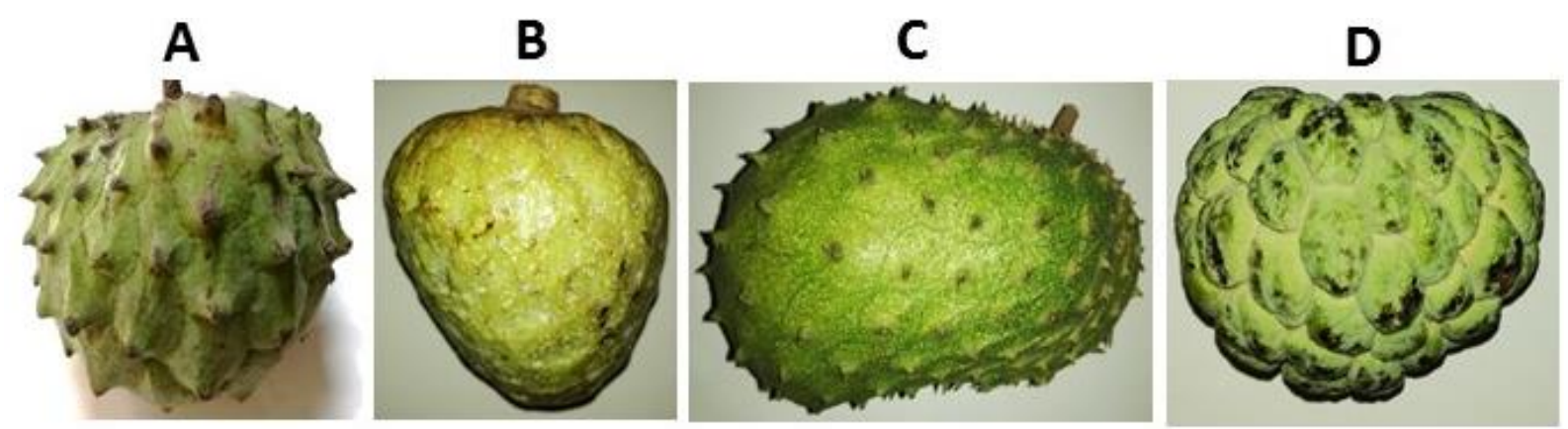

Figure 1. Annona species A: Atemoya (Annona atemoya), B: Bullock's heart (Annona reticulata), C: Soursop (Annona muricata) and D: Sugar apple (Annona squamosa) used in the study. 
Determination of Physical Parameters

During the storage period, fruit fresh weight loss $\%\left(\mathrm{~g} \mathrm{~kg}^{-1}\right)$ was estimated as follows,

Fresh weight loss $\%=\frac{W_{1}-W_{2}}{W_{1}} \times 100$

where, $W_{1}=$ Initial weight of fruits $(g)$ and $W_{2}=$ Weight of fruits in 2, 4, 6 and 8 days after treatment .

Firmness was determined by using fruit firmness tester (FHP-803, Agriculture Solutions LLC, USA), by puncturing the fruits at four places in radial axis with the plunger and the required pressure was recorded $(\mathrm{N})$.

The colour of the fruit peel was determined as $L^{*}, a^{*}, b^{*}$ values using a colorimeter (CR-400, Minolta, Osaka, Japan). The colour parameters were represented by $L^{*}$ value (brightness of fruits) 0 (black) to 100 (white), $a^{*}$ value positive (reddish) to negative (greenish) values, $b^{*}$ value positive (yellowish) to negative (bluish).

\section{Determination of Chemical Parameters}

The Total Soluble Solid (TSS) content of fruits was estimated using the digital refractometer (ORD 85BM, Kern
Optics). The Titratable Acidity (TA) was determined using the official method described by the Association of Official Agricultural Chemists (AOAC, 2005). The results were expressed as the percentage of citric acid,

$$
\begin{aligned}
& T A(\%) \\
& =\frac{[\mathrm{ml} \mathrm{NaOH} \text { used }] \times[\mathrm{N} . \text { of a. }] \times \text { eq. wt. of acid }}{\text { Weight of the sample }(\mathrm{g})} \times 100
\end{aligned}
$$

where,

Normality (N.) of alkali (a.) $=0.1 \mathrm{eq} / \mathrm{L}$ and equivalent weight of acid (Citric) $=$ 0.064 .

\section{Statistical Analysis}

Data were subjected to correlation and regression analysis using SAS university edition and graphical analysis using Minitab 2018 and MS Excel 2013 package.

\section{RESULTS AND DISCUSSION}

\section{Post-harvest Life}

Among the Annona species, Atemoya recorded the highest post-harvest life ( 8 days) without treatment. None of the other three species were viable beyond 6 days without treatments. Soursop and Sugar apple fruits were viable beyond 8 
days only at 0.6 and $0.9 \mu \mathrm{L} \mathrm{L}^{-1} 1-\mathrm{MCP}$ concentrations. In contrast, Bullock's heart fruits were not viable beyond 6 days even after treatments. Therefore, Soursop and Sugar apple were shown a better response to 1-MCP treatments at 0.6 and $0.9 \mu \mathrm{L} \mathrm{L}^{-1}$ concentrations.

\section{Fresh Weight Loss of Annona}

Annona is marketed as a fresh product based on its weight. Therefore, postharvest weight loss directly affects the farmer's income. The highest rate of fresh weight loss during the postharvest period was recorded in Atemoya (30.5 $\left.\mathrm{g} \mathrm{kg}^{-1} \mathrm{day}^{-1}\right)$ and that was lowest in Bullock's heart (18.5 $\mathrm{g} \mathrm{kg}^{-1}$ day $^{-1}$ ) (Figure 2).

In all Annona species, the application of 1-MCP significantly reduces the rate of weight loss. It could be observed as the slope difference between two regression lines $\left(5.8 \mathrm{~g} \mathrm{~kg}^{-1}\right.$ day $^{-1}$ ) as indicated in Figure 3. This could be due to irreversibly binding of 1-MCP to the ethylene receptors and blocking the actions of the ethylene (Hofman et al., 2001). Moreover, less respiration and lower ethylene evolution rate delayed fruit ripening (rigid tissues) and thereby reduce the transpiration losses (Hofman et al., 2001).

The rate of fresh weight loss after harvesting at different treatment levels is given in Table 1. Accordingly, weight loss of all four Annona species has shown a strong positive correlation with time (days after harvesting). The 1-MCP substantially reduced the weight loss in all cultivars. Atemoya, Bullock's heart and Soursop have shown the highest retardation of weight loss at $0.6 \mu \mathrm{L} \mathrm{L}^{-1}$ concentration of 1-MCP while the Sugar apple was at $0.9 \mu \mathrm{L} \mathrm{L}^{-1}$. A slight increase in weight loss rate at $0.9 \mu \mathrm{L} \mathrm{L}^{-1}$ concentration was observed in Atemoya, Bullock's heart and Soursop cultivars. Higher concentrations of 1-MCP may be toxic to the Annona fruits and it may promote the decay of fruits (Blankenship and Dole, 2003). Greater weight loss in Sugar apple at $0.3 \mu \mathrm{L} \mathrm{L}^{-1}$ concentration of 1-MCP might be due to an insufficient level of chemicals to saturate the ethylene receptors. Feng et al. (2000) reported that 1-MCP treatment had delayed the ripening of avocado and their results are in agreement with the present study of Annona. 


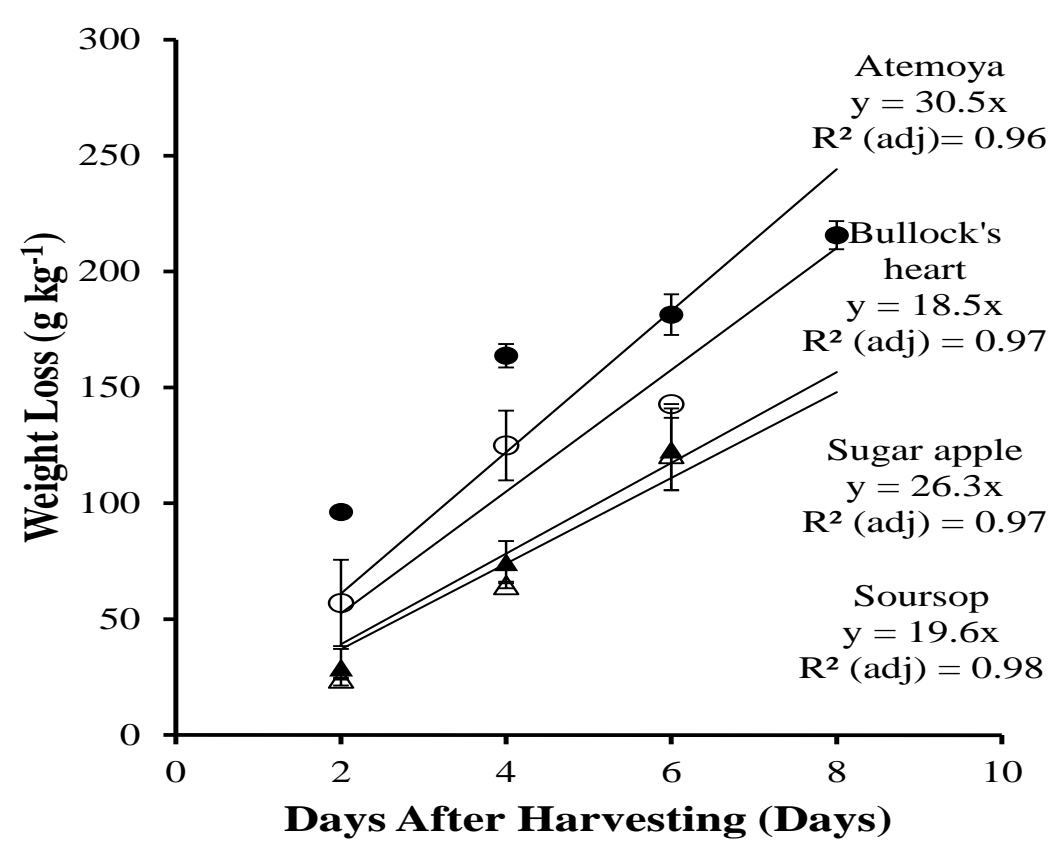

Figure 2. Rate of fresh weight loss after harvesting in Atemoya (closed circle), Bullock's heart (open triangle), Soursop (closed triangle) and Sugar apple (open circle), Annona species. $\mathrm{R}^{2}$ (adj) is the adjusted $r$ squired value (Mean \pm St.err; $\mathrm{n}=3$ ).

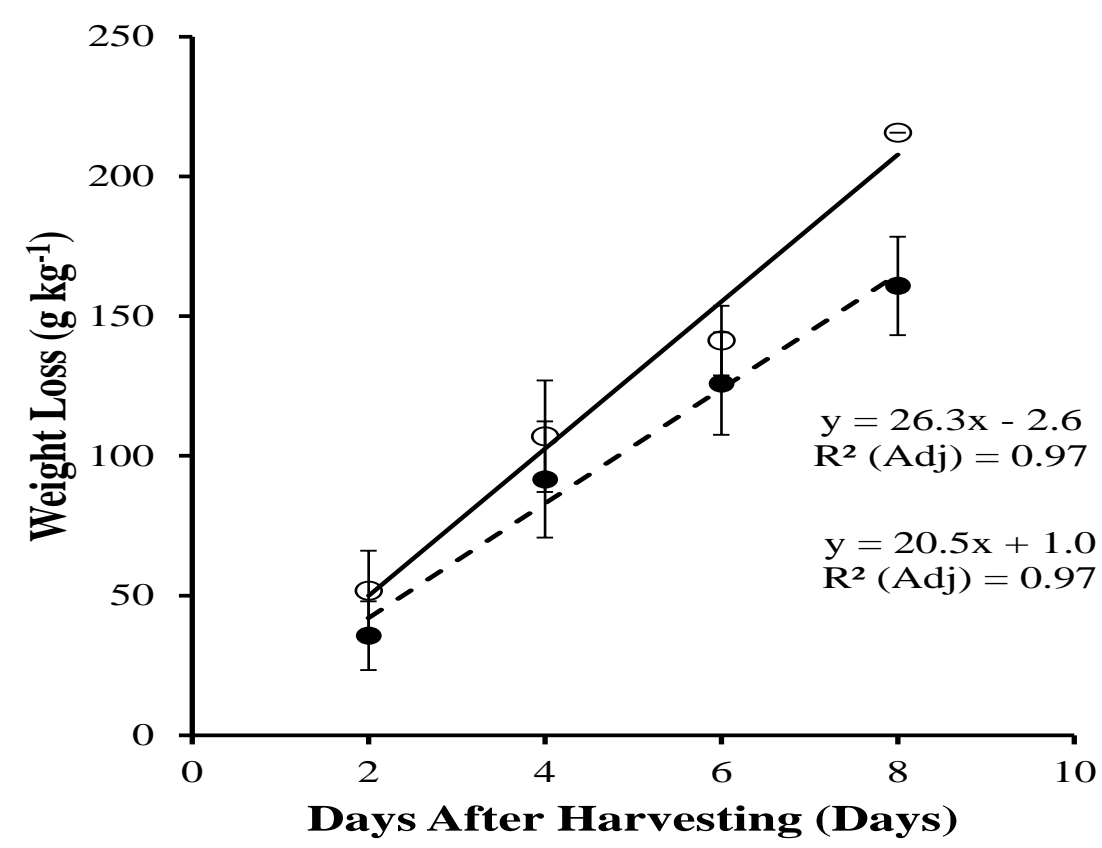

Figure 3. Rate of fresh weight loss after harvesting in 1-MCP treated (closed symbols) and nontreated (open symbols) Annona species (Atemoya, Bullock's heart, Soursop and Sugar apple). $R^{2}(\operatorname{adj})$ is the adjusted $r$ squired value (Mean \pm St.err; non- treated $n=3$ and treated $n=9$ ). 


\section{The Firmness of Annona (N)}

Regardless of cultivars, fruit firmness shows a strong negative correlation with time (Days after harvesting) (Table 2). Even though 1-MCP 0.6 and $0.9 \mu \mathrm{L}$
$\mathrm{L}^{-1}$ treatments were able to retard the firmness loss in comparison to control treatment $\left(0.0 \mu \mathrm{L}^{-1}\right), \quad 0.3 \quad \mu \mathrm{L}^{-1}$ concentration showed some inadequacy.

Table 1. Postharvest weight loss of four Annona species (Atemoya, Bullock's heart, Sugar apple and Soursop) at four different 1-MPCA treatments levels (T1, T2, T3 and T4). Weight loss ( $\mathrm{g} \mathrm{kg}^{-1}$ of fruit fresh weight) was measured at 2,4,6,8 and 10 days after harvesting. Rate of weight loss is given as regression coefficient $\left(\mathrm{g}\right.$ day $\left.{ }^{-1}\right)$. Correlation coefficient indicates the strength of the relationship between weight loss and time (days after harvesting).

\begin{tabular}{|c|c|c|c|}
\hline Species & Treatment & $\begin{array}{c}\text { Regression } \\
\text { coefficient }\end{array}$ & $\begin{array}{l}\text { Correlation } \\
\text { coefficient }\end{array}$ \\
\hline \multirow[t]{4}{*}{ Atemoya } & 1-MCP $0.0 \mu \mathrm{L} \mathrm{L}^{-1}$ (T1) & -12.3 & -0.94 \\
\hline & 1-MCP $0.3 \mu \mathrm{L} \mathrm{L}^{-1}(\mathrm{~T} 2)$ & -13.5 & -0.84 \\
\hline & 1-MCP $0.6 \mu \mathrm{L} \mathrm{L}^{-1}$ (T3) & -13.4 & -0.94 \\
\hline & 1-MCP $0.9 \mu \mathrm{L} \mathrm{L}^{-1}(\mathrm{~T} 4)$ & -11.3 & -0.95 \\
\hline \multirow{4}{*}{$\begin{array}{l}\text { Bullock's } \\
\text { heart }\end{array}$} & 1-MCP $0.0 \mu \mathrm{L} \mathrm{L}^{-1}(\mathrm{~T} 1)$ & -12.8 & -0.90 \\
\hline & 1-MCP $0.3 \mu \mathrm{L} \mathrm{L}^{-1}(\mathrm{~T} 2)$ & -12.7 & -0.97 \\
\hline & 1-MCP $0.6 \mu \mathrm{L} \mathrm{L}^{-1}(\mathrm{~T} 3)$ & -11.6 & -0.97 \\
\hline & 1-MCP $0.9 \mu \mathrm{L} \mathrm{L}^{-1}(\mathrm{~T} 4)$ & -13.9 & -0.91 \\
\hline \multirow{4}{*}{$\begin{array}{l}\text { Sugar } \\
\text { apple }\end{array}$} & 1-MCP $0.0 \mu \mathrm{L} \mathrm{L}^{-1}(\mathrm{~T} 1)$ & -12.4 & -0.58 \\
\hline & 1-MCP $0.3 \mu \mathrm{L} \mathrm{L}^{-1}(\mathrm{~T} 2)$ & -16.7 & -0.95 \\
\hline & 1-MCP $0.6 \mu \mathrm{L} \mathrm{L}^{-1}$ (T3) & -11.5 & -0.88 \\
\hline & 1-MCP $0.9 \mu \mathrm{L} \mathrm{L}^{-1}(\mathrm{~T} 4)$ & -10.8 & -0.94 \\
\hline \multirow[t]{4}{*}{ Soursop } & 1-MCP $0.0 \mu \mathrm{L} \mathrm{L}^{-1}(\mathrm{~T} 1)$ & -15.4 & -0.86 \\
\hline & 1-MCP $0.3 \mu \mathrm{L} \mathrm{L}^{-1}(\mathrm{~T} 2)$ & -13.9 & -0.89 \\
\hline & 1-MCP $0.6 \mu \mathrm{L} \mathrm{L}^{-1}$ (T3) & -13.0 & -0.98 \\
\hline & 1-MCP $0.9 \mu \mathrm{L} \mathrm{L}^{-1}(\mathrm{~T} 4)$ & -12.9 & -0.95 \\
\hline
\end{tabular}


Table 2. Variation in fruit firmness of four Annona species (Atemoya, Bullock's heart, Sugar apple and Soursop) at four different 1-MPCA treatments levels (T1, T2, T3 and T4). Fruit firmness (N) was measured at 2,4,6,8 and 10 days after harvesting. Rate of firmness loss is given as regression coefficient $\left(\mathrm{N} \mathrm{day}^{-1}\right)$. Correlation coefficient indicates the strength and direction of the relationship between firmness loss and time (days after harvesting).

\begin{tabular}{|c|c|c|c|}
\hline Species & Treatment & $\begin{array}{l}\text { Regression } \\
\text { coefficient }\end{array}$ & $\begin{array}{l}\text { Correlation } \\
\text { coefficient }\end{array}$ \\
\hline \multirow[t]{4}{*}{ Atemoya } & 1-MCP $0.0 \mu \mathrm{L} \mathrm{L}^{-1}(\mathrm{~T} 1)$ & 30.5 & 0.95 \\
\hline & 1-MCP $0.3 \mu \mathrm{L} \mathrm{L}^{-1}(\mathrm{~T} 2)$ & 27.3 & 0.95 \\
\hline & 1-MCP $0.6 \mu \mathrm{L} \mathrm{L}^{-1}(\mathrm{~T} 3)$ & 26.6 & 0.95 \\
\hline & 1-MCP $0.9 \mu \mathrm{L} \mathrm{L}^{-1}(\mathrm{~T} 4)$ & 26.7 & 0.94 \\
\hline \multirow{4}{*}{$\begin{array}{l}\text { Bullock's } \\
\text { heart }\end{array}$} & 1-MCP $0.0 \mu \mathrm{L} \mathrm{L}^{-1}(\mathrm{~T} 1)$ & 18.5 & 0.94 \\
\hline & 1-MCP $0.3 \mu \mathrm{L} \mathrm{L}^{-1}(\mathrm{~T} 2)$ & 14.1 & 0.99 \\
\hline & 1-MCP $0.6 \mu \mathrm{L} \mathrm{L}^{-1}(\mathrm{~T} 3)$ & 12.4 & 0.97 \\
\hline & 1-MCP $0.9 \mu \mathrm{L} \mathrm{L}^{-1}(\mathrm{~T} 4)$ & 13.4 & 0.99 \\
\hline \multirow{4}{*}{$\begin{array}{l}\text { Sugar } \\
\text { apple }\end{array}$} & 1-MCP $0.0 \mu \mathrm{L} \mathrm{L}^{-1}(\mathrm{~T} 1)$ & 26.3 & 0.81 \\
\hline & 1-MCP $0.3 \mu \mathrm{L} \mathrm{L}^{-1}(\mathrm{~T} 2)$ & 28.4 & 0.98 \\
\hline & 1-MCP $0.6 \mu \mathrm{L} \mathrm{L}^{-1}$ (T3) & 23.9 & 0.95 \\
\hline & 1-MCP $0.9 \mu \mathrm{L} \mathrm{L}^{-1}(\mathrm{~T} 4)$ & 22.6 & 0.99 \\
\hline \multirow[t]{4}{*}{ Soursop } & 1-MCP $0.0 \mu \mathrm{L} \mathrm{L}^{-1}(\mathrm{~T} 1)$ & 19.6 & 0.91 \\
\hline & 1-MCP $0.3 \mu \mathrm{L} \mathrm{L}^{-1}(\mathrm{~T} 2)$ & 17.0 & 0.96 \\
\hline & 1-MCP $0.6 \mu \mathrm{L} \mathrm{L}^{-1}(\mathrm{~T} 3)$ & 16.9 & 0.95 \\
\hline & 1-MCP $0.9 \mu \mathrm{L} \mathrm{L}^{-1}(\mathrm{~T} 4)$ & 20.3 & 0.93 \\
\hline
\end{tabular}

Paull et al. (1983) have reported the polygalacturonase (PG) and cellulase (endo-1.4, $\beta$-glucanase) enzymatic activities on fruit softening and they have indicated that treatments $(1-\mathrm{MCP})$ may have inhibited those enzymatic activities in the fruits. Retardation of firmness loss in Mango due to 1-MCP treatment, reported by Li et al. (2020) is 
in agreement with the present study for Annona.

\section{Peel Colour Changes of Annona}

(a) L*Value (Luminosity Value)

Change of Luminosity $\left(L^{*}\right)$ value of Bullock's heart, Sugar apple and Soursop did not show any correlation with time. In contrast, it was positively correlated in Atemoya. At the time of harvesting $L^{*}$ value of Atemoya fruits were in the range of $52.1 \pm 0.2$ and that was the highest at the well-ripening stage (82.6 \pm 6.2$)$. The correlation coefficient of $\mathrm{L}^{*}$ value and the time for T1 $\left(0.0 \mu \mathrm{L} \mathrm{L}^{-1}\right), \mathrm{T} 2\left(0.3 \mu \mathrm{L} \mathrm{L}^{-1}\right), \mathrm{T} 3(0.6 \mu \mathrm{L}$ $\left.\mathrm{L}^{-1}\right)$ and $\mathrm{T} 4\left(0.9 \mu \mathrm{L} \mathrm{L}^{-1}\right)$ were $0.85,0.85$ 0.61 and 0.41 , respectively. Moreover, regression coefficients for the treatments of $\mathrm{T} 1, \mathrm{~T} 2, \mathrm{~T} 3$ and $\mathrm{T} 4$ were $8.8,6.7,4.4$ and 2.5, respectively. This indicates the retardation of change of $L^{*}$ value in Atemoya with the increasing 1MCP concentration (from 0.3 to $0.9 \mu \mathrm{L}$ $\left.\mathrm{L}^{-1}\right)$.

(b) $a^{*}$ Value (Red-green Value)

At the time of harvesting, $a^{*}$ value of all Annona cultivars was negative (Atemoya -11.6 \pm 0.08 , Bullock's heart 10.1 \pm 1.0 , Sugar apple $-8.5 \pm 0.2$ and Soursop $-13.9 \pm 0.5$ ) and it indicates the greenness of peel. Even though $a^{*}$ vale of Atemoya and Soursop shows a positive correlation (0.83 and 0.75, respectively) with time, $a^{*}$ value was positive only in Atemoya $(4.1 \pm 0.4)$ at the well-ripening stage. This indicates some reddish color development in peel. However, application of 1-MCP was unable to alter the rate of change of $\mathrm{a}^{*}$ with respect to $1-\mathrm{MCP}$. Therefore, $\mathrm{a}^{*}$ value may not be a good single indicator to detect Annona ripening.

\section{(c) $b^{*}$ Value (Yellow-blue Value)}

Positive $b^{*}$ value indicates the yellowness of fruits. However, yellowness $\left(b^{*}\right)$ of Bullock's heart, Sugar apple and Soursop fruits did not change during the study period. In contrast that showed a strong positive correlation with time (correlation coefficient of $\mathrm{T} 1 ; 0.85)$ in Atemoya. The correlation coefficient of $b^{*}$ value at the time of T1, T2, T3 and T4 were 0.85, $0.79, \quad 0.76$ and 0.32 , respectively. Moreover, regression coefficients for the above T1, T2, T3 and T4 treatments were $4.4,2.8,1.7$ and 0.5 , respectively. Therefore, the application of 1-MCP retards the development of yellowness in Atemoya fruits. Chlorophyll degradation is mainly caused by an increase in either or both 
chlorophyllase and peroxidase enzymatic activity (Wang et al., 2009). Those enzymatic activities are increased by ethylene during fruit ripening (Charoenchongsuk et al., 2015).

Change of peel colour, (measured by $L^{*}, a^{*}$ and $b^{*}$ ) would be good indicators to detect the fruit ripening at least for Atemoya. Accordingly, retardation of peel colour development owing to the application of 1-MCP, indicate the potential of 1-MCP as a post-harvest treatment. Therefore, this response of the present study can be attributed to the observations of Harris et al. (2000) who reported longer green life of fruits after 1-MCP application. Moreover, present study shows some discrepancy with the Siang et al. (2019) who reported ability of 1-MCP to preserve peel colour of local Soursop. According to present study, there was no significant effect of $1-\mathrm{MCP}$ on Soursop peel colour.

\section{Total Soluble Solids (\% TSS) of Annona}

Strong positive correlation between TSS and time (days after harvesting) was observed in Atemoya (Table 3). The rate of TSS production in T1 $\left(0.0 \mu \mathrm{L} \mathrm{L}^{-1}\right), \mathrm{T} 2$ $\left(0.3 \mu \mathrm{L} \mathrm{L}^{-1}\right), \mathrm{T} 3\left(0.6 \mu \mathrm{L} \mathrm{L}^{-1}\right)$ and $\mathrm{T} 4(0.9$ $\mu \mathrm{L} \mathrm{L}^{-1}$ ) were $1.61,1.48,1.49$ and 1.27, respectively. Therefore, it indicates the retardation of TSS production rate with the application of 1-MCP in Atemoya. However, TSS production in other cultivars did not show any significant response to applied 1-MCP. According to present study, the effect of 1-MCP on TSS is cultivar dependent and it is in agreement with Blankenship and Dole (2003). The result of present study shows some discrepancies with Siang et al. (2019) who reported a reduction of TSS with 1-MCP application in Soursop. It could be possible due to variation in other factors such as storage conditions. Blankenship and Dole (2003), have revealed that the fruits stored under normal ambient conditions increased their TSS value than the fruits stored under controlled atmospheric conditions. Then the effect of only 1-MCP cannot clearly be observed.

\section{Titratable Acidity (TA \%)}

A strong positive correlation of Titratable acidity and time (days after harvesting) was observed in Atemoya (correlation coefficient 0.96), Bullock's heart (correlation coefficient 0.76) and Soursop (correlation coefficient 0.85) (Table 4). However, application of 1- 
MCP was unable to alter the synthesis rate of titratable acidity in Atemoya. Therefore, present study is in agreement with Silva et al. (2016) who reported no significant effect of 1-MCP on titratable acidity in Atemoya. In contrast, due to greater scattered-ness of observed data it is difficult to identify the effect of 1-MCP in Bullock's heart and Soursop species. Therefore, postharvest synthesis of Titratable acidity could be a species-dependent factor.

Table 3. Variation in total soluble solids (TSS) of four Annona species (Atemoya, Bullock's heart, Sugar apple and Soursop) at four different 1-MPCA treatments levels (T1, T2, T3 and T4). TSS (\%) was measured at 2,4,6,8 and 10 days after harvesting. Rate of TSS change is given as regression coefficient $\left(\%\right.$ day $\left.^{-1}\right)$. Correlation coefficient indicates the strength and direction of the relationship between TSS and time (days after harvesting).

\begin{tabular}{|c|c|c|c|}
\hline Species & Treatment & $\begin{array}{l}\text { Regression } \\
\text { coefficient }\end{array}$ & $\begin{array}{l}\text { Correlation } \\
\text { coefficient }\end{array}$ \\
\hline \multirow[t]{4}{*}{ Atemoya } & 1-MCP $0.0 \mu \mathrm{L} \mathrm{L}^{-1}(\mathrm{~T} 1)$ & 1.61 & 0.92 \\
\hline & 1-MCP $0.3 \mu \mathrm{L} \mathrm{L}^{-1}(\mathrm{~T} 2)$ & 1.48 & 0.91 \\
\hline & 1-MCP $0.6 \mu \mathrm{L} \mathrm{L}^{-1}(\mathrm{~T} 3)$ & 1.49 & 0.88 \\
\hline & 1-MCP $0.9 \mu \mathrm{L} \mathrm{L}^{-1}(\mathrm{~T} 4)$ & 1.27 & 0.95 \\
\hline \multirow{4}{*}{$\begin{array}{l}\text { Bullock's } \\
\text { heart }\end{array}$} & 1-MCP $0.0 \mu \mathrm{L} \mathrm{L}^{-1}(\mathrm{~T} 1)$ & 3.95 & 0.52 \\
\hline & 1-MCP $0.3 \mu \mathrm{L} \mathrm{L}^{-1}(\mathrm{~T} 2)$ & 3.90 & 0.61 \\
\hline & 1-MCP $0.6 \mu \mathrm{L} \mathrm{L}^{-1}(\mathrm{~T} 3)$ & 3.79 & 0.56 \\
\hline & 1-MCP $0.9 \mu \mathrm{L} \mathrm{L}^{-1}(\mathrm{~T} 4)$ & 2.76 & 0.42 \\
\hline \multirow[t]{4}{*}{ Sugar apple } & 1-MCP $0.0 \mu \mathrm{L} \mathrm{L}^{-1}(\mathrm{~T} 1)$ & 0.13 & 0.03 \\
\hline & 1-MCP $0.3 \mu \mathrm{L} \mathrm{L}^{-1}(\mathrm{~T} 2)$ & 0.67 & 0.45 \\
\hline & 1-MCP $0.6 \mu \mathrm{L} \mathrm{L}^{-1}(\mathrm{~T} 3)$ & 0.27 & 0.12 \\
\hline & 1-MCP $0.9 \mu \mathrm{L} \mathrm{L}^{-1}(\mathrm{~T} 4)$ & 1.31 & 0.56 \\
\hline \multirow[t]{4}{*}{ Soursop } & 1-MCP $0.0 \mu \mathrm{L} \mathrm{L}^{-1}(\mathrm{~T} 1)$ & 0.69 & 0.48 \\
\hline & 1-MCP $0.3 \mu \mathrm{L} \mathrm{L}^{-1}(\mathrm{~T} 2)$ & 0.20 & 0.15 \\
\hline & 1-MCP $0.6 \mu \mathrm{L} \mathrm{L}^{-1}(\mathrm{~T} 3)$ & 0.65 & 0.63 \\
\hline & 1-MCP $0.9 \mu \mathrm{L} \mathrm{L}^{-1}(\mathrm{~T} 4)$ & 1.22 & 0.76 \\
\hline
\end{tabular}


Table 04 Variation in Titratable acidity of four Annona species (Atemoya, Bullock's heart, Sugar apple and Soursop) at four different 1-MPCA treatments levels (T1, T2, T3 and T4). Titratable acidity was measured at 2,4,6,8 and 10 days after harvesting. Rate of Titratable acidity change is given as regression coefficient $\left(\%\right.$ day $\left.^{-1}\right)$. Correlation coefficient indicates the strength and direction of the relationship between TSS and time (days after harvesting).

\begin{tabular}{|c|c|c|c|}
\hline Species & Treatment & $\begin{array}{l}\text { Regression } \\
\text { coefficient }\end{array}$ & $\begin{array}{l}\text { Correlation } \\
\text { coefficient }\end{array}$ \\
\hline \multirow[t]{4}{*}{ Atemoya } & 1-MCP $0.0 \mu \mathrm{L} \mathrm{L}^{-1}(\mathrm{~T} 1)$ & 0.03 & 0.96 \\
\hline & 1-MCP $0.3 \mu \mathrm{L} \mathrm{L}^{-1}$ (T2) & 0.05 & 0.87 \\
\hline & 1-MCP $0.6 \mu \mathrm{L} \mathrm{L}^{-1}(\mathrm{~T} 3)$ & 0.04 & 0.78 \\
\hline & 1-MCP $0.9 \mu \mathrm{L} \mathrm{L}^{-1}(\mathrm{~T} 4)$ & 0.05 & 0.97 \\
\hline Bullock's & 1-MCP $0.0 \mu L^{-1}(\mathrm{~T} 1)$ & 0.07 & 0.76 \\
\hline \multirow[t]{3}{*}{ heart } & 1-MCP $0.3 \mu \mathrm{L} \mathrm{L}^{-1}(\mathrm{~T} 2)$ & 0.01 & 0.16 \\
\hline & 1-MCP $0.6 \mu \mathrm{L} \mathrm{L}^{-1}$ (T3) & 0.03 & 0.27 \\
\hline & 1-MCP $0.9 \mu \mathrm{L} \mathrm{L}^{-1}(\mathrm{~T} 4)$ & 0.02 & 0.30 \\
\hline \multirow[t]{4}{*}{ Sugar apple } & 1-MCP $0.0 \mu \mathrm{L} \mathrm{L}^{-1}(\mathrm{~T} 1)$ & 0.01 & 0.15 \\
\hline & 1-MCP $0.3 \mu \mathrm{L} \mathrm{L}^{-1}(\mathrm{~T} 2)$ & 0.01 & 0.08 \\
\hline & 1-MCP $0.6 \mu \mathrm{L} \mathrm{L}^{-1}$ (T3) & 0.06 & 0.83 \\
\hline & 1-MCP $0.9 \mu \mathrm{L} \mathrm{L}^{-1}(\mathrm{~T} 4)$ & 0.01 & 0.15 \\
\hline \multirow[t]{4}{*}{ Soursop } & 1-MCP $0.0 \mu \mathrm{L} \mathrm{L}^{-1}(\mathrm{~T} 1)$ & 0.16 & 0.85 \\
\hline & 1-MCP $0.3 \mu \mathrm{L} \mathrm{L}^{-1}(\mathrm{~T} 2)$ & 0.17 & 0.63 \\
\hline & 1-MCP $0.6 \mu L^{-1}$ (T3) & 0.05 & 0.25 \\
\hline & 1-MCP $0.9 \mu \mathrm{L} \mathrm{L}^{-1}(\mathrm{~T} 4)$ & 0.09 & 0.63 \\
\hline
\end{tabular}

Titratable acidity increases owing to organic acids production during the fruit ripening. However, towards the end of ripening process titratable acidity decreased due to consumption of organic acids (i.e. malic acids and citric acids) as substrates in respiratory processes (Alves et al., 2004; Abbasi et al., 2009).

Means of physical and chemical parameters (Weight loss, firmness, peel colour $\mathrm{L}^{*}, \mathrm{a}^{*}$ and $\mathrm{b}^{*}$, total soluble solids and titratable acidity) at initial (2 days 
Table 5. Means of postharvest physical and quality parameters of Annona fruits at initial (2 DAT) and last day of the storage period (6/ 8 DAT)

\begin{tabular}{|c|c|c|c|c|c|c|c|c|c|}
\hline \multirow{2}{*}{ Parameter } & \multirow{2}{*}{ Treatment } & \multicolumn{2}{|c|}{ Atemoya } & \multicolumn{2}{|c|}{ Bullock's heart } & \multicolumn{2}{|c|}{ Soursop } & \multicolumn{2}{|c|}{ Sugar apple } \\
\hline & & 2DAT & 8DAT & 2DAT & 6DAT & 2DAT & 6DAT & $2 \mathrm{DAT}$ & 6DAT \\
\hline \multirow[t]{4}{*}{ Weight loss (g/kg) } & $\mathrm{T} 1$ & $96.3 \pm 1.1$ & $215.7 \pm 4.9$ & $24.3 \pm 0.4$ & $117.6 \pm 12.7$ & $29.3 \pm 6.4$ & $123.3 \pm 14.5$ & $57.0 \pm 15.2$ & $142.8 \pm 0.0$ \\
\hline & $\mathrm{T} 2$ & $68.1 \pm 3.8$ & $200.7 \pm 6.7$ & $7.1 \pm 0.4$ & $85.7 \pm 3.1$ & $30.1 \pm 3.1$ & $98.9 \pm 4.3$ & $43.7 \pm 1.9$ & $175.3 \pm 9.0$ \\
\hline & $\mathrm{T} 3$ & $61.8 \pm 2.1$ & $194.8 \pm 0.8$ & $7.1 \pm 0.4$ & $82.1 \pm 8.9$ & $29.2 \pm 3.6$ & $97.6 \pm 6.8$ & $35.7 \pm 3.2$ & $146.3 \pm 13.3$ \\
\hline & $\mathrm{T} 4$ & $69.7 \pm 0.9$ & $192.4 \pm 6.3$ & $6.6 \pm 0.2$ & $80.1 \pm 2.8$ & $32.9 \pm 2.3$ & $128.2 \pm 13.1$ & $35.7 \pm 1.6$ & $140.8 \pm 2.8$ \\
\hline \multirow[t]{4}{*}{ Firmness (N) } & T1 & $96.8 \pm 2.1$ & $26.8 \pm 9.1$ & $91.3 \pm 4.4$ & $39.5 \pm 15.8$ & $94.9 \pm 2.5$ & $33.1 \pm 5.3$ & $80.2 \pm 4.2$ & $69.7 \pm 0.0$ \\
\hline & $\mathrm{T} 2$ & $106.4 \pm 4.2$ & $23.6 \pm 0.0$ & $99.8 \pm 0.3$ & $57.4 \pm 0.5$ & $100.4 \pm 0.5$ & $44.6 \pm 0.9$ & $95.6 \pm 3.7$ & $28.6 \pm 3.7$ \\
\hline & $\mathrm{T} 3$ & $120.5 \pm 3.0$ & $37.6 \pm 6.9$ & $107.0 \pm 2.2$ & $69.3 \pm 2.4$ & $103.5 \pm 2.6$ & $55.8 \pm 0.0$ & $97.0 \pm 4.3$ & $48.7 \pm 0.1$ \\
\hline & $\mathrm{T} 4$ & $136.4 \pm 4.7$ & $72.2 \pm 12.7$ & $100.0 \pm 3.2$ & $49.8 \pm 11.5$ & $101.9 \pm 1.6$ & $45.8 \pm 0.0$ & $105.2 \pm 4.0$ & $67.4 \pm 5.7$ \\
\hline \multirow[t]{4}{*}{ Peel colour $L^{*}$ value } & T1 & $52.5 \pm 0.8$ & $75.4 \pm 03.3$ & $60.4 \pm 3.3$ & $65.0 \pm 2.3$ & $52.7 \pm 1.0$ & $53.0 \pm 2.0$ & $54.7 \pm 0.2$ & $54.3 \pm 0.9$ \\
\hline & $\mathrm{T} 2$ & $53.0+1.7$ & $74.7 \pm 02.2$ & $63.1 \pm 1.0$ & $61.9 \pm 0.7$ & $51.1 \pm 0.8$ & $52.8 \pm 1.6$ & $54.0 \pm 1.4$ & $53.8 \pm 1.9$ \\
\hline & T3 & $51.5 \pm 1.1$ & $60.2 \pm 07.7$ & $61.3 \pm 0.2$ & $57.9 \pm 0.6$ & $49.6 \pm 0.8$ & $50.0 \pm 1.3$ & $54.1 \pm 1.1$ & $53.6 \pm 1.3$ \\
\hline & $\mathrm{T} 4$ & $52.4 \pm 0.3$ & $61.9 \pm 07.3$ & $61.6 \pm 1.0$ & $59.2 \pm 4.4$ & $52.0 \pm 0.5$ & $52.1 \pm 1.3$ & $54.5 \pm 0.6$ & $53.5 \pm 0.8$ \\
\hline \multirow[t]{4}{*}{ Peel colour $a^{*}$ value } & T1 & $-9.4 \pm 1.6$ & $3.6 \pm 00.7$ & $-0.9 \pm 3.4$ & $2.9 \pm 2.4$ & $-13.6 \pm 0.2$ & $-11.6 \pm 0.2$ & $-8.6 \pm 0.1$ & $-5.2 \pm 1.5$ \\
\hline & $\mathrm{T} 2$ & $-11.1 \pm 0.4$ & $0.4 \pm 02.8$ & $-7.5 \pm 1.3$ & $-5.1 \pm 2.2$ & $-13.8 \pm 0.2$ & $-11.4 \pm 0.6$ & $-8.6 \pm 0.4$ & $-5.8 \pm 0.6$ \\
\hline & $\mathrm{T} 3$ & $-9.9 \pm 0.4$ & $-1.3 \pm 02.4$ & $-7.0 \pm 0.8$ & $-6.8 \pm 0.9$ & $-13.7 \pm 0.7$ & $-11.8 \pm 1.2$ & $-9.1 \pm 0.6$ & $-7.2 \pm 0.4$ \\
\hline & $\mathrm{T} 4$ & $-11.2 \pm 0.2$ & $-6.5 \pm 01.5$ & $-6.2 \pm 0.9$ & $-6.1 \pm 0.1$ & $-13.5 \pm 0.3$ & $-10.1 \pm 0.6$ & $-8.4 \pm 0.3$ & $-7.9 \pm 0.3$ \\
\hline
\end{tabular}


G.P.M Wijesinghe, G.D.K Kumara and J.B.D.A.P Kumara

\begin{tabular}{lcccccccccc}
\hline Peel colour $\boldsymbol{b}$ value & $\mathrm{T} 1$ & $27.4 \pm 0.3$ & $53.9 \pm 4.6$ & $34.3 \pm 1.1$ & $36.9 \pm 0.7$ & $34.3 \pm 1.2$ & $36.7 \pm 2.1$ & $25.4 \pm 0.5$ & $27.2 \pm 2.3$ \\
& $\mathrm{~T} 2$ & $27.5 \pm 0.1$ & $43.3 \pm 2.1$ & $34.3 \pm 0.4$ & $34.6 \pm 0.2$ & $32.9 \pm 0.5$ & $31.8 \pm 1.0$ & $25.4 \pm 0.5$ & $26.4 \pm 3.0$ \\
& $\mathrm{~T} 3$ & $26.7 \pm 0.7$ & $36.3 \pm 3.4$ & $32.1 \pm 0.4$ & $32.7 \pm 0.8$ & $31.7 \pm 1.3$ & $31.2 \pm 2.3$ & $26.6 \pm 0.7$ & $24.7 \pm 0.5$ \\
& $\mathrm{~T} 4$ & $27.1 \pm 0.9$ & $29.9 \pm 3.7$ & $32.3 \pm 1.5$ & $31.6 \pm 1.8$ & $33.9 \pm 1.1$ & $33.2 \pm 0.6$ & $26.7 \pm 0.2$ & $24.8 \pm 0.9$ \\
\hline $\begin{array}{l}\text { Total soluble } \\
\text { solids (\%) }\end{array}$ & $\mathrm{T} 1$ & $10.6 \pm 0.3$ & $20.3 \pm 0.7$ & $13.7 \pm 4.3$ & $20.4 \pm 2.4$ & $13.9 \pm 1.1$ & $17.2 \pm 0.9$ & $21.1 \pm 1.6$ & $20.1 \pm 0.0$ \\
& $\mathrm{~T} 2$ & $11.7 \pm 0.7$ & $20.7 \pm 0.3$ & $11.2 \pm 2.0$ & $19.0 \pm 3.1$ & $13.7 \pm 0.7$ & $15.4 \pm 0.7$ & $18.8 \pm 2.8$ & $21.3 \pm 0.5$ \\
& $\mathrm{~T} 3$ & $12.1 \pm 0.2$ & $20.9 \pm 0.4$ & $8.6 \pm 0.4$ & $15.7 \pm 2.0$ & $12.2 \pm 1.4$ & $16.5 \pm 0.0$ & $19.7 \pm 3.8$ & $21.7 \pm 0.5$ \\
& $\mathrm{~T} 4$ & $10.8 \pm 0.3$ & $19.9 \pm 0.1$ & $11.3 \pm 4.5$ & $17.5 \pm 2.9$ & $8.6 \pm 0.9$ & $17.9 \pm 0.3$ & $13.4 \pm 2.0$ & $17.2 \pm 2.0$ \\
\hline $\begin{array}{l}\text { Titratable acidity } \\
\text { (\%) }\end{array}$ & $\mathrm{T} 1$ & $0.17 \pm 0.0$ & $0.34 \pm 0.0$ & $0.37 \pm 0.0$ & $0.52 \pm 0.0$ & $0.43 \pm 0.1$ & $0.69 \pm 0.0$ & $0.40 \pm 0.0$ & $\#$ \\
& $\mathrm{~T} 2$ & $0.16 \pm 0.0$ & $0.39 \pm 0.0$ & $0.46 \pm 0.0$ & $0.48 \pm 0.0$ & $0.36 \pm 0.1$ & $0.69 \pm 0.1$ & $0.38 \pm 0.0$ & $0.39 \pm 0.1$ \\
& $\mathrm{~T} 3$ & $0.13 \pm 0.0$ & $0.35 \pm 0.1$ & $0.39 \pm 0.0$ & $0.48 \pm 0.1$ & $0.34 \pm 0.1$ & $0.63 \pm 0.0$ & $0.32 \pm 0.0$ & $0.41 \pm 0.0$ \\
& $\mathrm{~T} 4$ & $0.11 \pm 0.0$ & $0.41 \pm 0.0$ & $0.43 \pm 0.0$ & $0.46 \pm 0.0$ & $0.26 \pm 0.0$ & $0.64 \pm 0.0$ & $0.35 \pm 0.0$ & $0.38 \pm 0.0$
\end{tabular}

DAT is the days after treatment, \# missing data, Treatments T1,T2, T3 and T4 are 1-MCP concentrations 0, 0.3, 0.6 and $0.9 \mu L L^{-1}$ respectively. Mean \pm St.Err (n=3) 
after treatments) and end of the postharvest periods (6-8 days after treatment) were given in Table 5 . Accordingly, Annona species treated with 1-MCP were characterized by greater firmness at the end of 6 to 8 days. Moreover, 1-MCP treatments decrease the weight loss in Atemoya and Bullock's heart species at all levels of treatments.

\section{CONCLUSION}

According to the study, application of 1-MCP retard the loss of fruit fresh weight, firmness, total soluble solids and titratable acidity in Annona species. Considering all 1-MCP concentration levels and Annona species, $0.6 \mu \mathrm{L} \mathrm{L}^{-1}$ was identified as the most promising treatment among the tested ones. Among the indices used to estimate the peel colour, $\mathrm{L}^{*}$ and $\mathrm{b}^{*}$ values were more promising and Atemoya species was more sensitive for those indices. In conclusion, $0.6 \mu \mathrm{L} \mathrm{L}^{-1}$ 1-MCP would be a promising postharvest treatment for Annona and it requires further studies to evaluate different methods and time of 1-MCP applications before the recommendation.

\section{REFERENCES}

Abbasi, N.A., Iqbal, Z., Maqbool M. and Hafiz, I.A. (2009). Postharvest quality of mango (Mangifera indica L.) fruit as affected by chitosan coating. Pakistan Journal of Botany, 41(1): 343-357.

Alves, R.E., Filgueiras, H.A.C., Almeida, A.S., Pereira, M.E.C., Cocozza, F.M. and Jorge, J.T. (2004). Postharvest ripening of 'Tommy Atkins' mangoes on two maturation stages treated with 1-MCP. Acta Horticulture, 645: 627-632.

AOAC. (2005). Official methods of analysis (18 ${ }^{\text {th }}$ edition). Association of Official Analytical Chemists, Arlington, VA, USA.

Blankenship, S.M. and Dole, J.M. (2003). 1-Methylcyclopropene: a review. Postharvest Biology and Technology. 28: $1-25$.

Bruinsma, J. and Paull, R.E. (1984). Respiration during postharvest development of soursop fruit, Annona muricata L. Plant physiology, 76:131-138.

Burg, S.P. and Burg, E.A. (1967). Molecular requirements for the biological activity of ethylene. Plant Physiology, 42: 144-152.

Charoenchongsuk, N., Ikeda, K., Itai, A., Oikawa, A. and Murayama, $\mathrm{H}$. (2015). Comparison of the expression of chlorophylldegradation-related genes during ripening between stay-green and 
yellow-pear cultivars. Science and Horticulture, 18: 994.

Dilrukshi, M.K.D.T., Dharmadasa, R.M., Abeysinghe, D.C. and Abhayagunasekara, A.V.C. (2020). Selection of superior quality Annona species by means of bioactive compounds and antioxidant capacity. World Journal of Agricultural Research, 8(2): 39-44.

Ekanayake, S. and Bandara, L. (2002). Development of banana leather. Annals of the Sri Lanka Department of Agriculture, 4: 353-358.

FAO. (2018). Statistics. Food and Agriculture Organization of United Nations (FAO). http://www.FAO.org.

Feng, X., Apelbau, A., Sisler, E.C. and Goren, R. (2000). Control of ethylene responses in avocado fruit with 1methylcyclopropene. Postharvest Biology and Technology, 20(2): 143150. DOI: 10.1016/S09255214(00)00126-5.

Gautam, D.M and Bhattarai, (2012). Postharvest horticulture. Bhawani Printers, Chabahil, Kathmandu, Nepal.

Harris, D.R., Seberry, J.A., Wills, R. and Spohr, L. (2000). Effect of fruit maturity on efficiency of 1-MCP to delay the ripening of bananas. Postharvest Biology and Technology, 20(3): 303-308. DOI: 10.1016/S09255214(00)00150-2.

Heenkenda, H.M.S., Gunathilaka, B.L. and Iswara, J.P. (2009). Rootstockscion interactions of selected
Annona species. Journal of National Science Foundation, Sri Lanka, 37(1): 21-75.

Hofman, P. J., Jobin-Décor, M., Meiburg, G. F., Macnish, A. J. and Joyce, D. C. (2001). Ripening and quality responses of Avocado, Custard apple, Mango and Papaya fruit to 1-Methylcyclopropene. Australian Journal of Experimental Agriculture, 41: 567-572.

Khalid, M.A., Nisar, A.S., Muhammad, I. and Arshad, F. (2011). Postharvest losses and marketing of grapes in Pakistan. Journal of Agriculture, 27(3): 485-490.

Leliévre, J.M., Latché, A., Jones, B., Bouzayen, M., Pech, J.C. (1997). Ethylene and fruit ripening. Physiologia Plantarum, 1001: 727-739.

Li, L., Li, C., Sun, J., Sheng, J. , Zhou, Z., Xin, M., Yi, P., He, X., Zheng, F., Tang, Y., Li, J. and Tang, J. (2020). The effects of 1-methylcyclopropene in the regulation of antioxidative system and softening of mango fruit during storage. Journal of Food Quality, 2020, Article ID: 6090354. DOI: $10.1155 / 2020 / 6090354$.

Mahajan, P.V., Caleb, O.J., Singh, Z., Watkins, C.B. and Geyer, M. (2014). Postharvest treatments of fresh produce. Philosophical Transaction of the Royal Society, 372: 20130309. doi.org/10.1098/rsta.2013.0309

Paull, R.E. (1983). Postharvest variation in composition of soursop (Annona muricata L.) fruit in relation to respiration and ethylene 
production. Journal of the American Society for Horticultural Science, 107: 582-585.

Prasanna, K.N.V., Rao, D.V.S. and Krishnamurthy, S. (2000). Effect of storage temperature on ripening and quality of custard apple (Annona squamosa L.). Journal of Horticultural Science and Biotechnology, 75: 546-550.

Ramady, H.R.E., Domokos-Szabolcsy, E., Abdalla, N.A., Taha, H.S. and Far, M. (2015). Postharvest management of fruits and vegetables storage. Sustainable Agriculture Reviews, $15 . \quad$ DOI 10.1007/978-3-319-09132-7_2.

Ratnayake, S.S., Kumar, L. and Kariyawasam, C.S. (2019). Neglected and underutilized fruit species in Sri Lanka: Prioritisation and understanding the potential distribution under climate change. Agronomy.

DOI: 10.3390/agronomy10010034.

Siang, L.M., Mahamed, M.T.M. and Ding, P. (2019). Response of 1methylcyclopropene on postharvest quality of local soursop (Annona muricata L.). Sains Malayasians, 48(3): 571-579.

Silva, G.M.C., Cordeiro, M.H.N., Mizobusti, G.P., Sobral, R.R.S., Gisele, P., Mizobutshi, E.H., Silva, N., Feitosa, F.M., Martins, J.C. and Fonseca, S.N.A. (2016). 1-MCP extends atemoya shelf life. Journal of Food, Agriculture and Environment, 14(1): 35-39.
Sisler, E.C. and Serek, K. (1997). Inhibitors of ethylene responses in plant at the receptor level: recent development. Physiologia Plantarum, 100: 577-582.

Tomala, K., Małachowska, M., Guzek, D., Głabska, D. and Gutkowska, K. (2020). The effects of 1methylcyclopropene treatment on the fruit quality of 'Idared' apples during storage and transportation. Agriculture, 10: $490 . \quad$ DOI: 10.3390/agriculture10110490.

Tucker, G., Yin, X., Zhang, A., Wang, M., Zhu, Q., Liu, X., Xie, X., Chen, K., and Grierson, D. (2017). Ethylenet and fruit softening. Food Quality and Safety, 1: 253-267.

Wang, B., Wang, J., Feng, X., Lin, L., Zhao, Y. and Jiang, W. (2009). Effects of 1-MCP and exogenous ethylene on fruit ripening and antioxidants in stored mango. Plant Growth Regulation, 57: 185-192.

Wasala, W.M.C.B., Dissanayaket, C.A.K., Dharmasena, D.A.N., Gunawardane, C.R. and Dissanayake, T.M.R. (2014). Postharvest losses, current issues and demand for postharvest technologies for loss management in the main banana supply chains in Sri Lanka. Journal of Postharvest Technology, 2(1): 80-87. 